\title{
Determining Practices of Classroom Teachers Who Have Mainstreaming and Special Needs Students in Their Classes
}

\author{
Pelin Gur ${ }^{*}(\mathbb{D})$, Ahmet Yikmis² \\ ${ }^{1}$ Near East University, Department of Special Education, Nicosia, Mersin 10, Turkey, e-mail: pelin.gur@neu.edu.tr \\ ${ }^{2}$ Bolu Abant Izzet Baysal University, Department of Special Education, Bolu, Turkey, e-mail: yikmis_a@ibu.edu.tr
}

\begin{abstract}
The aim of this research is to determine, interpret and provide recommendations on instructional practices and evaluation of classroom teachers working with mainstreaming students at schools in the North Cyprus. A qualitative research method was used in the research. Data was collected through semi-structured interviews as one of the qualitative data collection methods. The interview form used in the research included 10 questions related to design and teaching practices as well as evaluation of the effectiveness of the instruction. Interviews were conducted with 12 classroom teachers working at mainstreaming classes under the North Cyprus Ministry of National Education and all interviews were recorded. These data were transferred to a digital environment where they were interpreted as code titles. The results showed that classroom teachers carry out in-class practices for teaching methods and activities of their mainstreaming students, and benefit from visual materials that they prepared with an assistant teacher. However, the classroom teachers also stated that they are unable to allocate time for their mainstreaming students because of the large numbers of students in the class and therefore they send their mainstreaming students to the special education teachers in their schools. It was determined that classroom teachers make their evaluations based on the level, interest and ability of students when evaluation the effectiveness of teaching.
\end{abstract}

Keywords: Mainstreaming education, Instructional practices, Evaluation in Education, mainstreaming in North Cyprus.

\section{Introduction}

Individuals with special needs are defined as people with different needs compared with their peers in terms of all developmental characteristics (Hornby, 2015; Sagiroglu and Uzunboylu, 2018). Inclusion refers to the special inclusion of children with special needs in the education and training of class peers with normal development. In other words, it is the process of facilitating more constructive psycho-social relations of children with special needs (Zagona, Kurth and MacFarland, 2017). The main purpose of mainstreaming education is that individuals with special needs receive education with their normal peers who do not need special education. Mainstreaming education is carried out full-time and part-time. Parttime mainstreaming is carried out by individuals with special needs in some classes with their peers in or out of the classroom. All of the individual's needs should be taken into consideration when planning part-time and full-time mainstreaming education (Batu, 2000; Delubom, Marongwe and Buka, 2020). Today, with the advances in the education system, it is possible to meet all of the educational needs of individuals with special needs and for them to receive education together with their peers through mainstreaming education (Forlin et al. 2009; Oncul, 2003; Coskun, Gur and Aykutlu, 2014). When individuals with disabilities are educated in the same environment with their peers, it is observed that their learning speeds increase in the academic and social sense and their communication skills are positively affected by observing and imitating their peers. It is also emphasized that when they are accepted by their peers in the school environment, they become more confident in society. According to the literature, when the academic development between the children attending special education institution and the children attending mainstreaming class is compared, it can be said that the academic development of those studying in mainstreaming environments is faster (Anilan and Kayacan, 2015; Gavish, 2017).

In order to benefit the individuals with special needs in inclusion education, it is important to make the education environment of the children with special needs suitable and to provide the materials in the support education class when necessary (Gavish, 2017; Anilan and Kayacan, 2015). Research shows "Corresponding author: pelin.gur@neu.edu.tr 
that the personal characteristics of teachers affect their teaching. Teachers' intelligence, tolerance, proper communication skills, professional background and field knowledge determines the success of their teaching. Therefore, research on teacher behavior has increased (Wenglinsky, 2000; Cochran-Smith, 2001). Research has shown that when teachers have positive attitudes towards mainstreaming, they can easily adapt to meet the learning needs of mainstreaming students (Elsayed and Salama, 2020). Consequently, teachers having sufficient knowledge and skills is an important factor in the development of positive attitudes towards mainstreaming education (Voltz, Brazil and Ford, 2008; Orel, Zerey and Toret 2004). In the study conducted by Gozun and Yikmis (2004), it was concluded that classroom teachers receiving inclusion education were more favorable to inclusion education practices than classroom teachers not receiving education.

The most important factor in the successful implementation and execution of mainstreaming is classroom teachers (Sabayleh and Alramamneh, 2020). Teachers should be willing and positive about their duties in mainstreaming education. Classroom teachers, who have children with special needs in their class, individualize and evaluate the teaching considering the differences of students with special needs. Within this framework, families work in cooperation with related institutions and organizations (Sucuoglu and Akalin 2010). It is especially important for teachers to accept their students with special needs, get to know them well and approach them selflessly. Individualized education programs should be prepared for the students with special needs and correct evaluations should be performed by teaching according to the interests and abilities of the students. The physical structure of the classroom, which is the in-class arrangement, should be organized according to the child and appropriate materials should be prepared for the lesson. Class teachers should work in collaboration with other teachers (Ozkan and Tokel, 2020). Acceptance of students with special needs in the classroom by their peers depends on the peer information to be made by the class teacher and the preparation of the class for mainstreaming education (Guleryuz, 2009).

The knowledge of the personnel involved in mainstreaming education is generally limited (Aravind and Refugio, 2019). For this reason, classroom teachers have particular difficulties in providing successful education in inclusion education. (Anilan and Kayacan, 2015). In-service trainings should be organized, and classroom teachers should be provided with information about special education. Teachers need to understand the type of disability of the child well and make classroom arrangements, instructional adaptation and evaluation accordingly. It is especially important that teachers are willing, patient and selfless in the mainstreaming process (Anilan and Kayacan, 2015; Sahin, 2010). Vural and Yikmis (2008) emphasized that the instructional practices in inclusion practices are of great importance for the achievement of the desired success in the education of students with special needs. Therefore, classroom teachers have a significant role in the teaching and evaluation phase of inclusion practices. In addition, in terms of children with normal development, their behaviors such as respect, help, tolerance and understanding are positively affected by receiving education with their peers with special needs. Class teachers should prepare programs according to the interests and abilities of the students and increase the interaction of the students by organizing in-class activities (Gul and Vuran, 2015). Jacob and Olisaemeka (2016) listed the most important factors of inclusion in their study as preparing programs to meet the needs of the students, adapting teaching, using teaching methods and techniques that the student will understand and providing support education services. Looking at the research that reveal the problems that classroom teachers experience with regard to teaching practices in mainstreaming practices, we can say that teachers use different materials for the students with special needs during the lesson and explain the information to be given in the simplest form, yet they still need support in the process of instructional adaptation and evaluation (Sadioglu, 2011).

It is necessary to make adaptations to the course contents and class order for students with special needs who receive inclusion education (Taspinar, 2019). Appropriate materials that consider the special needs of the students and are in accordance with the courses planned should be used. In order for inclusion education to be successful, classroom teachers should be equipped with instructional practice and evaluation (Olcay-Gul, 2014; Shaw, 2011). If the physical structure of the classroom, materials used in teaching, adaptations in instructional practices and assessment are not suitable according to the individual's disability status, interests and skills, inclusion education will not have a positive effect on the individual (Pliner and Johnson, 2004; Uzunboylu, 2019). It should be noted that different materials that appeal to different senses and different methods, such as cooperative learning, learning by discovery and direct instruction, should be used besides the plain narrative method in the classrooms where students receive mainstreaming education, as they have different needs as well as development and learning characteristics and therefore cannot benefit equally from the uniform education offered to them. Peer support and teaching must be included in the teaching and learning processes (Gul and Vuran, 2015; 
Evans et al., 2010).

When working with students with special needs, assignments should be given according to the development of the students based on their in-class situation, and the assessment should be made in accordance with the student's interests and abilities, and most importantly, the deficiency rate (Zeff, 2007). When we examine the studies carried out with classroom teachers regarding mainstreaming education, we see that in-service training for special education field knowledge is of great importance for positive opinions and effective education according to the opinions of classroom teachers about the mainstreaming practice (Demir and Acar 2010; Ozaydin and Colak 2011; Calisoglu and Tanisir, 2018). As a result of some research, it was found that there are negativities related to inclusion. It was concluded that mainstreaming education could not be realized as desired due to reasons such as the physical structure of the school and the unsuitable class size, the unequal distribution of inclusion students to the classes, the demands of the classroom teachers not being met, insufficient material support, and insufficient inservice trainings despite the fact that the teachers received assistance from the training support teachers (Sarac and Colak 2012; Guzel 2014; Yaman 2017). When the studies were examined in general, it was found that classroom teachers emphasized that they did not find themselves sufficient about inclusion education, that support education services and material support were not provided, and that they wanted to improve themselves in relation to the education of students with special needs but they did not receive education support in this sense (Dagli and Oznacar, 2015; Germano, Brito and Capellini, 2017; Sardohan and Akcamete, 2018; Bayrakli and Sucuoglu, 2018). In order to be effective in mainstreaming education, it is of great importance to determine the actions of classroom teachers regarding instructional practice and evaluation, and to take necessary precautions and to provide the necessary support in this area. The aim of this research is to determine what primary school teachers who work in mainstreaming schools in the TRNC and who are mainstreaming students in their classroom do with regard to instructional and evaluation practices.

\section{Materials and Methods}

The qualitative research method was used in order to determine what teachers do in terms of instructional practice and evaluation in mainstreaming practices. The information collected by the qualitative research technique varies. Data obtained from this approach can be in the form of observation notes, interview records, documents, pictures and other forms. The interview method was also used in this study. The interview technique is divided into structured, semi-structured and unstructured. As a data collection tool, a semi-structured interview form was developed by the researchers. In the semi-structured interview technique, questions were asked to the interviewees in a systematic order and the participants were allowed to answer freely (Buyukozturk et al., 2017). The first version of the form used in the study was open-ended, consisting of ten questions: six questions about patterning and practicing instruction and four questions about evaluating the effectiveness of instruction.

\section{Study Group}

This study was carried out to determine the activities of classroom teachers with mainstreaming students working in primary schools about instructional practice and evaluation in mainstreaming practices. In this research, data was collected by interviewing teachers who worked in primary schools with mainstreaming students in their classes. The study group of this research consists of 12 mainstreaming class teachers working in primary schools with resource rooms in accordance with the permission obtained from the TRNC Ministry of National Education.

\section{Demographic Information on Teachers}

Table 1 shows the gender, age, and seniority information of the teachers in the research, whether the teachers had received mainstreaming education, the period for which they had worked in the mainstreaming class and the faculties from which they had graduated. Alphabetical codes were assigned to each of the teachers participating in the research. 
Table 1

Demographic Information on Teachers

\begin{tabular}{|c|c|c|c|c|c|c|}
\hline $\begin{array}{l}\text { The Code of } \\
\text { the Teacher }\end{array}$ & Gender & Age & Seniority & $\begin{array}{c}\text { Received } \\
\text { Mainstreaming } \\
\text { Training before }\end{array}$ & $\begin{array}{l}\text { How Long He/She } \\
\text { Had Been Working } \\
\text { with the Inclusion } \\
\text { Class }\end{array}$ & Faculty \\
\hline A & Female & $26-30$ & $0-5$ & Yes & $0-5$ years & Teacher Academy \\
\hline$B$ & Female & $26-30$ & $6-10$ & Yes & $0-5$ years & Teacher Academy \\
\hline $\mathrm{C}$ & Male & $\begin{array}{l}41 \text { and } \\
\text { above }\end{array}$ & $16-20$ & Yes & $6-10$ years & Teacher Academy \\
\hline D & Female & $31-35$ & $11-15$ & Yes & $11-15$ years & Teacher Academy \\
\hline$E$ & Female & $\begin{array}{l}41 \text { and } \\
\text { above }\end{array}$ & $\begin{array}{l}21 \text { and } \\
\text { above }\end{array}$ & No & 21 years and above & $\begin{array}{l}\text { Faculty of } \\
\text { Education }\end{array}$ \\
\hline $\mathrm{F}$ & Female & $36-40$ & $16-20$ & Yes & $0-5$ years & Teacher Academy \\
\hline G & Female & $36-40$ & $11-15$ & No & $0-5$ years & $\begin{array}{l}\text { Faculty of } \\
\text { Education }\end{array}$ \\
\hline $\mathrm{H}$ & Female & $\begin{array}{l}41 \text { and } \\
\text { above }\end{array}$ & $16-20$ & No & $11-15$ years & $\begin{array}{l}\text { Faculty of } \\
\text { Education }\end{array}$ \\
\hline I & Male & $\begin{array}{l}41 \text { and } \\
\text { above }\end{array}$ & $16-20$ & No & $0-5$ years & Teacher Academy \\
\hline $\mathrm{K}$ & Female & $36-40$ & $16-20$ & No & $0-5$ years & Teacher Academy \\
\hline $\mathrm{L}$ & Female & $31-35$ & $6-10$ & Yes & $0-5$ years & Teacher Academy \\
\hline M & Male & $\begin{array}{l}41 \text { and } \\
\text { above }\end{array}$ & $16-20$ & Yes & $0-5$ years & Teacher Academy \\
\hline
\end{tabular}

\section{Data Collection}

In this study, the data was collected by using the semi-structured interview method, which is one of the qualitative data collection techniques. An interview form consisting of ten questions was used in order to determine the activities of the classroom teachers with mainstreaming students towards instructional practice and evaluation. The questions are as follows:

(1) What are the adaptations that teachers make in teaching methods and activities in line with the educational needs of students with special needs?

(2) What measures are taken by teachers to facilitate the interaction of students with special needs with other students?

(3) What kind of materials do teachers prepare for students with special needs?

(4) What kind of support did the teachers receive regarding the teaching of students with special needs and what do they do about this subject?

(5) What are the problems that classroom teachers experience in designing and implementing instruction in mainstreaming and what do they do to overcome these problems?

(6) What do classroom teachers do to improve their skills in designing and applying instruction in mainstreaming?

To evaluate the effectiveness of teaching:

(1) What do the classroom teachers do with regard to evaluating the effectiveness of the instruction they perform with the students with special needs in mainstreaming?

(2) What do the classroom teachers do during the mainstreaming process to share the evaluation results with the special needs student, their family and other staff working with the student?

(3) What do the classroom teachers do with the evaluation results in the mainstreaming practice when determining the educational objectives?

(4) What do classroom teachers do to improve their skills in assessing teaching effectiveness?

The interview questions were asked to the participants according to the determined order and if the answer to a subsequent question was given while answering that question, it was not asked again. 
During the interview, any part of the questions that the teachers did not understand was explained. The explanation was done in a way that prevented the interviewer from shoving a particular idea that could cause the interviewee to give an expected response. In the following parts of the study, the names of the teachers who participated in the interview have been coded for ethical reasons.

\section{Data Analysis}

The sound recordings collected for the research were written on papers and every word heard during this casting was transferred to the computer verbatim. After the recordings were transferred and edited, each line was given a number and the sound recordings were listened to again and compared with the transferred text in order to check the accuracy of the data. A total of 20 pages were obtained from the data gathered from all the interviews. In order to encode the data, data with meaning integrity was determined and a coding list was obtained. The data showing meaningful equality were themed. The themes were presented in percentages and frequency tables and shared in the findings section. In the process of data analysis, codes and themes were interpreted in a comprehensible language and the results were determined.

\section{Validity and Reliability}

In this study, the opinions of two experts were taken for the interview questions that were firstly prepared within the scope of the validity and reliability studies, then a pilot scheme was applied with the interview questions and the questions were finalized. Subsequently, the researcher asked all questions in the same order with the same sentences during each interview and the data were collected by recording the sound. The data transferred from the audio recording was transferred to a computer and then transcribed. For the reliability of this document, an expert instructor wrote a randomly selected audio recording. The obtained documents were compared with each other and the reliability study was conducted. Subsequently, expert opinion was continually received during the coding and thematization of the data and finalized.

\section{Results}

\section{Students \\ The Views of Classroom Teachers on Designing and Practicing Teaching for Mainstreaming}

Primary school teachers were asked six questions in order to determine their views on "Designing and Practicing Instruction for Mainstreaming Students" and the answers given to these questions are explained below.

The views of teachers regarding the question "What kind of adaptations do you make in the teaching methods and activities in line with the educational needs of the students with Special Needs?" were as follows:

Table 2

Teachers' Views on Adaptations Made in Teaching Methods and Activities

\begin{tabular}{lll}
\hline Teachers' Views & f & $\%$ \\
\hline I seat my student at my desk or in the front row & 4 & 25 \\
I use visual materials prepared by a support education teacher or prepared by myself. & 4 & 25 \\
By giving different tasks to other children in the classroom, I can give one-to-one education & 2 & 12.5 \\
to the student with special needs. & & \\
As the class is crowded, I cannot allocate time to my special needs' student during class & 2 & 12.5 \\
hours. & & 12.5 \\
$\begin{array}{l}\text { He/she develops his/her academic skills with the help of a special education teacher or in a } \\
\text { special education center. }\end{array}$ & 2 & 12.5 \\
Ido not prepare a different activity during my course for students with special needs & 2 & 16 \\
Total & & 100 \\
\hline
\end{tabular}

When the answers of the class teachers to the questions asked about what they do in the teaching methods and activities of the students attending mainstreaming education are examined, it can be 
concluded that unlike the other students, mainstreaming students sit in the front row or at the teacher's desk, the teachers give different tasks to other students in the classroom in order to take care of the students with special needs. Teachers make use of the visual materials prepared by the support education teacher and themselves, and that they direct the student to the special education teacher in their academic classes because of the crowded class size.

Teachers' views about the question "What measures do you take to facilitate the interaction between the student with special needs and other students?" were as follows:

Table 3

Teachers' Views on the Measures Taken to Facilitate Interaction with Other Students

\begin{tabular}{llc}
\hline Teachers' Views & $\mathbf{f}$ & $\%$ \\
\hline I organize group activities and events to facilitate the interaction between & 7 & 35 \\
students with special needs and other students & & \\
At the beginning of the semester, I inform the peers about the students with & 6 & 30 \\
special needs. & \\
I ask my special needs student to sit with friends with whom he/she has a good & 2 & 10 \\
understanding & & 10 \\
He/she does not adapt and does not participate in the courses that he/she fails or & 2 & \\
finds difficult. & 2 & 10 \\
I give tasks to the students with special needs in class & 5 \\
I do not do anything additional for my students with special needs in terms of & 1 & 5 \\
interacting with their friends & 20 & 100 \\
Total & &
\end{tabular}

In the question posed to the classroom teachers to determine what they do to facilitate the interaction between the students with special needs and their peers, it was observed that group activities were conducted, some teachers informed their students about the status of the students with special needs at the beginning of the semester, some teachers gave certain tasks to their mainstreaming students and others encouraged the students with special needs to collaborate with other students with whom they could easily understand. In addition, it was concluded that some teachers did not implement any practices in order to integrate the students.

Teacher opinions about the question "What kind of materials do you prepare for students with special needs?" were as follows:

Table 4

Teachers' Views about Materials Prepared for Students with Special Needs

\begin{tabular}{lcc}
\hline Teachers' Views & $\mathbf{f}$ & $\%$ \\
\hline Apart from the textbooks related to the course, I make use of the materials I prepared & 5 & 33.4 \\
myself. & 3 & 20 \\
I usually use textbooks; I do not prepare any extra material & 3 & 20 \\
I use the material prepared by the special education teacher & 2 & 13.4 \\
I request lesson material from the family & 1 & 6.6 \\
We use materials from other private educational institutions & 1 & 6.6 \\
I take advantage of technology & 15 & 100 \\
Total
\end{tabular}

Looking at the answers to the question "what kind of materials do you prepare for the students with special needs?" that was directed to the classroom teachers, it was concluded that they provided education independent from the textbooks. They brought the materials from other special education institutions, they demanded the materials from the families, they benefited from the materials prepared by the special education teacher and themselves and that they also benefited from the technology. The answer "I do not use any additional material other than general textbooks" was also found among the findings. However, in general, the teachers stated that they found solutions for the material themselves and that the Ministry of National Education does not provide material support within the scope of inclusion.

The views of teachers regarding the question "What kind of support do you receive regarding the teaching of special needs students directed to classroom teachers? What do you do about this?" were as follows: 
Table 5

Teachers' Views Regarding Support Received During Teaching

\begin{tabular}{lcc}
\hline Teachers' Views & F & $\%$ \\
\hline We receive expert support from a special education teacher in our school & 12 & 66.6 \\
I do research about special education department (internet, books etc.). & 4 & 22.2 \\
We cooperate with families & 1 & 5.6 \\
We exchange ideas with other mainstreaming teachers. & 1 & 5.6 \\
Total & 18 & 100 \\
\hline
\end{tabular}

Looking at the answers to the question "what kind of support do you receive regarding the teaching of special needs students?" directed to the classroom teachers, it was concluded that they received the greatest help from the special education teachers in their schools, they exchanged information with other mainstream teachers, and they developed themselves by conducting research about the special education area.

The views of teachers regarding the question "What do you experience in designing and practicing instruction directed to classroom teachers? What would you suggest overcoming them?" were as follows:

Table 6

Teachers' Views about the Teaching and Design

\begin{tabular}{lcc}
\hline Teachers' Views & $\mathbf{f}$ & $\%$ \\
\hline $\begin{array}{l}\text { I receive the support of a special education teacher in the design and } \\
\text { application of teaching }\end{array}$ & 5 & 33.3 \\
I do research and practice according to the interests and abilities of the child & 5 & 33.3 \\
during the design and application phase of the teaching (Internet, books, etc.). & & \\
When I have difficulty, I take special care of the student & 2 & 13.4 \\
I do not make any additional applications for the student & 2 & 13.4 \\
I do not have any problems in designing and applying teaching & 1 & 6.6 \\
Total & 15 & 100 \\
\hline
\end{tabular}

Looking at the answers to the questions posed to the teachers in order to determine what they have experienced in designing and practicing instruction, they stated that they obtained special results in cases where they worked in cooperation with special education teachers, conducted research according to the interests and abilities of the child, and were challenged in teaching. In addition, there were teachers who said that they did not have any difficulties in designing the teaching method and did not make any additional applications in this regard.

Teachers' views on the question of "What do you do to increase your skills in designing and practicing teaching?" were as follows:

Table 7

Teachers' Views Regarding Support Received for Designing and Implementing Teaching

\begin{tabular}{lcc}
\hline Teachers' Views & f & $\%$ \\
\hline I get help from a special education teacher & 7 & 41.2 \\
I develop myself by doing research & 7 & 41.2 \\
I attend courses provided by the Ministry of Education & 3 & 17.6 \\
Total & 17 & 100 \\
\hline
\end{tabular}

Looking at the answers to the questions posed to the teachers in order to determine what they are doing in order to increase their skills in designing and practicing instruction, it was determined that they received help from the special education teacher in the school, they developed themselves by doing research about the special education field and they participated in the courses offered by the Ministry of Education within the scope of in-service trainings. 


\section{To evaluate the effectiveness of teaching}

Four questions were asked to the classroom teachers to determine their views on "Evaluating the Effectiveness of Teaching" and the answers given to these questions are explained below.

Teacher's opinions about the question "How do you evaluate the effectiveness of your teaching with special needs students?" were as follows:

\section{Table 8}

Teachers' Opinions on Evaluating the Effectiveness of Teaching

\begin{tabular}{lcc}
\hline Teachers' Views & $\mathbf{f}$ & $\%$ \\
\hline Unlike other peers in the classroom, I evaluate my mainstreaming students at & 9 & 75 \\
their own level. & & \\
Special education teacher makes the assessment & 2 & 16.6 \\
I do not make a different assessment & 1 & 8.4 \\
Total & 12 & 100 \\
\hline
\end{tabular}

When the answers given by the classroom teachers in terms of evaluating the effectiveness of teaching were examined, it was found that, unlike other peers in their classrooms, they evaluated inclusion students according to their level, interest and ability. In addition to this, it was observed that there were teachers who did not use a different assessment method, as well as schools where special education teachers conducted the evaluation.

Teacher opinions about the question "What do you do in in terms of sharing the evaluation results with the special needs student herself/himself, her/his family and other staff working with the student?" were as follows:

\section{Table 9}

Teachers' Views about Notifying the Student, Family and Other Personnel Working with Students with Special Needs About the Assessment Results

\begin{tabular}{lcc}
\hline Teachers' Views & f & $\%$ \\
\hline We inform family, special education teachers and administrators through & 11 & 91.6 \\
daily, weekly and annual meetings. & 1 & 8.4 \\
We put labels and icons on the studies and make notes. & 12 & 100 \\
\hline Total
\end{tabular}

With regard to the classroom teachers notifying the student himself / herself, his / her family and other staff working with the student about the evaluation results, it is concluded that they provide continuous information about the child's situation through daily, weekly and annual meetings, and they also put labels and symbols on the studies and provide feedback by taking notes.

Teachers' opinions about the question "How do you use the evaluation results to determine the educational objectives?" were as follows:

Table10

Teachers' Views on Using Evaluation Results in Determining Educational Objectives

\begin{tabular}{lcc}
\hline Teachers' Views & $\mathbf{f}$ & $\mathbf{\%}$ \\
\hline If the desired success is achieved as a result of the assessment, we move on to the next & & \\
level. If the achievement level does not reach the desired target, we do the same subject & 11 & 91.6 \\
with different teaching methods. & 1 & 8.4 \\
I use the results of the evaluation to see if the reinforcers are effective. & 12 & 100 \\
\hline
\end{tabular}

When the answers given by the classroom teachers about how they used the evaluation results to determine the educational goals were examined, it was concluded that if the desired achievement level was reached after the evaluation they continued with the next level, but if the achievement level was not reached, the teaching was repeated by using different teaching methods and materials.

Teachers' views on the question "What do you do to increase your skills in assessing the effectiveness of teaching?" were as follows: 
According to the answers given to the question pertaining to what classroom teachers were doing to increase their skills in evaluating the effectiveness of teaching, it was concluded that they read special education books, got help from special education teachers, did research on the internet and participated in courses opened by the Ministry of Education.

Table 11

Teachers' Views on What to Do to Increase Skills for Evaluating the Effectiveness of Teaching

\begin{tabular}{lcc}
\hline Teachers' Views & $\mathbf{f}$ & $\%$ \\
\hline I attend the courses offered by the Ministry of Education. & 5 & 38.46 \\
I get support from our special education teachers. & 3 & 23.08 \\
I read special education books; I participate in courses offered by the Ministry. & 2 & 15.38 \\
I am not doing anything extra. & 2 & 15.38 \\
I browse the internet. & 1 & 7.7 \\
Total & 13 & 100 \\
\hline
\end{tabular}

\section{Discussion}

When the answers given by the mainstreaming class teachers regarding the teaching methods and activities of the students are examined, it can be seen that the teachers providing one-on-one support to the students with special needs. Some of the teachers are unable to allocate additional time to the students due to the crowded class size and therefore the students with special needs are directed to the special education teacher in their schools. Harvey et al., (2010) concluded that in-service training may be the most appropriate solution to address the concerns of educators and change negative attitudes about mainstreaming education. In this respect, it should be ensured that classroom teachers develop themselves by participating in the necessary trainings (Sahamkhadam, 2020). In the study conducted by Sarac and Colak (2012), it was concluded that classroom teachers providing inclusion education received help from other staff in the school and that they did not receive adequate training in spite of the fact that they wanted to improve themselves. Due to the lack of a special education law in the TRNC, the infrastructure required for inclusion education is insufficient. The greatest deficiency is the lack of knowledge of classroom teachers who provide education in mainstreaming classes for students with special needs and a lack of in-service trainings on this issue. Excessive class size, lack of material support and lack of awareness among families can also be considered as negative factors (Erden, 2016).

According to peer information studies in mainstreaming education, normally developing peers have a more positive attitude towards students with special needs and make it easier to accept the situation of mainstreaming students (Krahe and Altwasser, 2006). In-class and out-of-class activities, other than academic courses, were found to have a positive effect on improving the communication between average children and special needs children. Through these activities, we can say that mainstreaming students and their normal peers interact and collaborate. (Gavish, 2017; Sadioglu, Batu and Bilgin, 2012). It is thought that classroom teachers working in mainstreaming class should receive support services in order to develop themselves in collaboration with experts and these services will positively affect mainstreaming education (Batu, 2000). In their study, Sarac and Colak (2012) stated that classroom teachers could not find the necessary support within the scope of inclusion and that their demands were not taken into consideration in terms of the problems they experienced, the physical conditions of the inclusion classes were not sufficient for the children, and that this support was inadequate although the classroom teachers cooperated with other staff. In a study conducted by Babaoglan and Yilmaz (2010), teachers stated that teachers who do not have the necessary knowledge about special education have difficulty in establishing a classroom authority and that teachers also have difficulties in the absence of the necessary support education services.

In mainstreaming classes, the lack of instructional adaptation by teachers, lack of acceptance by peers in children with special needs, and lack of legal deficiencies lead to major problems during the evaluation of mainstreaming students (Anilan and Kayacan, 2015). In order to develop a new teaching strategy, it is necessary to share the results of the evaluation with the family and other staff (Aytac, Demirbas-Celik and Kiracioglu, 2019). Accurate assessment of teaching and keeping results regularly are important in the context of making the right decisions in the transition to the next teaching period (Sahin, 2010). Classroom teachers with mainstreaming students in the classroom should be well equipped in the 
evaluation phase of the teaching as well as the adaptation stage (Sahamkhadam, 2020).

\section{Limitations and recommendations for further research}

From this point of view, in-service trainings should be provided to classroom teachers who provide mainstreaming education in schools where mainstreaming education is applied. Material support should be provided to schools where mainstreaming education is provided in primary schools. Appropriate distribution of mainstreaming students by supervising class sizes will positively affect mainstreaming education in primary schools. If we examine the obtained results from this qualitative study conducted with primary school teachers working in mainstreaming classes, in-service teacher training can be conducted and teachers' opinions and competences of pre-training and post-training can be compared. Within the scope of mainstreaming, research can be developed by conducting studies with school principals, education support teachers and families.

\section{Conclusion}

When the answers of the mainstreaming class teachers in the teaching methods and activities of the students are examined, the results of the research show that, the teachers seat their mainstreaming students in the front row or at the teachers' desks, giving different tasks to the other students in the classroom for giving one-on-one support to the students with special needs, In addition to the fact that they use visual materials, some of the teachers cannot allocate additional time to the students due to the crowded class size and therefore the students with special needs are directed to the special education teacher in their schools. Cankaya and Korkmaz (2012) stated that classroom teachers had physical deficiencies in mainstreaming education practices, and they found it difficult to find the materials to be used in the course. The teacher should be well equipped in terms of student motivation, gaining family support, adaptation of the students to the class and applying effective education methods (Sahamkhadam, 2020). When the answers given by the classroom teachers in terms of evaluating the effectiveness of teaching were examined, it was found that, unlike other peers in their classrooms, they evaluated inclusion students according to their level, interest and ability. In addition to this, it was observed that there were teachers who did not use a different assessment method. In addition to making educational adaptations in mainstreaming education, it is of great importance that appropriate conditions are provided for the students with special needs and to make the necessary arrangements during the evaluation phase of the education (Zeff, 2007; Aytac, 2020).

\section{Acknowledgements}

The authors are grateful to Assoc. Prof. Dr. Ahmet Yikmis who helped in the data collection process and to all participants of the study for always being there from the very beginning.

\section{Conflict of interests}

The authors declare no conflict of interest.

\section{References}

Abbasoglu, S. (2016). Özel Eğitim ve Kaynaştırma Eğitimi Uygulanan Illkokullarda Özel Eğitim Hizmetlerinin Öğretmen Görüşlerine Göre Değerlendirilmesi [Assessment of Special Education and Inclusive Education School Through Teachers Opinions]. (Yüksek lisans tezi). Yakın Doğu Üniversitesi, Eğitim Bilimleri Enstitüsü, Lefkoşa. Retrieved from http://docs.neu.edu.tr/library/6425501583.pdf

Anilan, H., \& Kayacan, G. (2015). The reality of mainstreaming education through the eyes of classroom teachers. Bartın University Faculty of Education Journal, 74-90. Retrieved from https://dergipark.org.tr/en/pub/buefad/issue/3817/51334

Aravind, V. R., \& Refugio, C. (2019). Efficient learning with intelligent tutoring across cultures. World Journal on Educational Technology: Current Issues, 11(1), 30-37. https://doi.org/10.18844/wjet.v1111.4007

Aytac Demircivi, K. (2020). Personal factors predicting EFL Learners' writing anxiety. Global Journal of Foreign Language Teaching, 10(4), 257-267. https://doi.org/10.18844/gjflt.v10i4.5104

Aytac, P., Demirbas-Celik, N., \& Kiracioglu, D. (2019). Effectiveness of family involvement activities in pre-school education. Global Journal of Guidance and Counseling in Schools: Current Perspectives, 9(3), 131-137. https://doi.org/10.18844/ gjgc.v9i3.4489

Babaoglan, E., \& Yilmaz, S. (2010). Competences of Classroom Teachers in Inclusion Education. Kastamonu Education Journal, 18(2), 345-354. Retrieved from https://dergipark.org.tr/en/pub/kefdergi/issue/49063/626026 
Gur, P., \& Yikmis, A. (2021). Determining practices of classroom teachers who have mainstreaming and special needs students in their classes, International Journal of Cognitive Research in Science, Engineering and Education (IJCRSEE), 9(2), 227-239.

Batu, E.S. (2000). Özel Gereksinimli Öğrencilerin Kaynaştırıldığı Bir Kız Meslek Lisesindeki Öğretmenlerin Kaynaştırmaya Karşılaşılan Sorunlara İlişkin Görüş ve Önerileri [Öpinions and Suggestions of Teachers in a Vocational High School for Girls, Where Students with Special Needs are Mainstreamed, on the Problems Encountered in Inclusion]. (Doktora Tezi). Anadolu Üniversitesi, Eskişehir. Retrieved from https://dspace.ankara.edu.tr/xmlui/bitstream/ handle/20.500.12575/47230/488.pdf?sequence=1\&isAllowed=y

Bayrakli, H., \& Sucuoglu, B. (2018). Empowering Mothers of Children with Special Needs in Early Childhood Inclusion. International Journal of Early Childhood Special Education, 10(2) Retrieved from https://www.int-jecse.net/data-cms/ articles/20200531115618pm512387.pdf

Buyukozturk, S., Akgun, O. E., Demirel, F., Karadeniz, S., \& Cakmak, EK (2017). Bilimsel araştırma yöntemleri [Scientific research methods]. Pegem Atıf Indeksi, 2017, 1-360. Retrieved from https://www.pegem.net/dosyalar/ dokuman/66011Bilimsel\%20Arast\%C4\%B1rma\%20Yontemleri.pdf

Calisoglu, M., \& Tanisir, Sn (2018). Investıgatıon of stakeholder opınıons on inclusıon educatıon in Prımary Schools [Investigation of stakeholder options on inclusion education in Primary Schools]. Ağrı Ibrahim Çeçen University Journal of Social Sciences Institute, 4(2), 21-45. https://doi.org/10.31463/aicusbed.465860

Cankaya, O. \& Korkmaz, I. (2012). Ilköğretim I. kademede kaynaştırma eğitimi uygulamalarının sınıf öğretmenlerinin görüşlerine göre değerlendirilmesi [Evaluation of inclusive education practices in primary education according to the opinions of classroom teachers]. Ahi Evran Üniversitesi Kırşehir Eğitim Fakültesi Dergisi, 13(1). Retrieved from http:/l acikerisimarsiv.selcuk.edu.tr:8080/xmlui/handle/123456789/6541

Cochran-Smith, M. (2001). Constructing outcomes in teacher education: Policy, practice and pitfalls. Education Policy Analysis Archives, 9, 1-34. https://epaa.asu.edu/ojs/article/view/340

Coskun, I., Gur, T. \& Aykutlu, H. (2014). Hafif düzey zihin engelli bireylerin okuduğunu anlama düzeyinin belirlenmesi ve yorumlanması amacıyla metin sonrası çizilen resimlerin incelenmesi [Examining the pictures drawn after the text in order to determine and interpret the reading comprehension level of mildly mentally retarded individuals]. Uluslararası Avrasya Sosyal Bilimler Dergisi, 5(14), 17-42. Retrieved from http://www.ijoess.com/makaleler/1526371564_ ibrahim\%20coskun17-42.pdf

Dagli, G., \& Oznacar, B. (2015). An Evaluation on Mainstreaming Practices of Primary Schools According to the Views of School Administrators, Teachers, and Parents. Educational Sciences: Theory and Practice, 15(5), 1317-1332. https:// doi.org/10.12738/estp.2015.5.2823

Delubom, N. E., Marongwe, N.., \& Buka, A. M. (2020). Managers' challenges on implementing inclusive education: Technical Vocational Education and Training Colleges. Cypriot Journal of Educational Sciences, 15(6), 1508-1518. https://doi. org/10.18844/cjes.v15i6.5294

Demir, M.K. \& Acar, S. (2010). Sınıf öğretmenlerinin kaynaştırma eğitimine ilişkin düşünceleri [Classroom teachers' thoughts on inclusive education]. Gazi Üniversitesi Gazi Eğitim Fakültesi Dergisi, 30(3), 749-770. Retrieved from http://www.gefad. gazi.edu.tr/tr/pub/issue/6740/90608

Elsayed, M., \& Salama, R. (2020). Educational games for miss-concentration students (ADHD students). International Journal of Innovative Research in Education, 7(1), 26-31. https://doi.org/10.18844/ijire.v7i1.4762

Erden, H. (2016). Qualification Journey in Teacher Training: Case in Northern Cyprus. Eurasian Journal of Educational Research, 65, 91-110. Retrieved from https://files.eric.ed.gov/fulltext/EJ1121903.pdf

Evans, C., Williams, J. B., King, L., \& Metcalf, D. (2010). Modeling, guided instruction, and application of UDL in a rural specail educationteacher preparation program. Rural Special Education Quarterly, 29, 41-48. https://doi.org/10.1177\% 2F875687051002900409

Forlin, C., Loreman, T., Sharma, U., \& Earle, C. (2009). Demographic differences in changing pre-service teachers 'attitudes, sentiments and concerns about mainstreaming education. International Journal of Mainstreaming Education.13(2), 195-209. https://doi.org/10.1080/13603110701365356

Gavish, B. (2017). The implementation of school inclusion practices for students with special needs in Israel: Teachers' perceptions. International Journal of Disability, Development and Education, 64(5), 544-560. https://doi.org/10.1080 $/ 1034912 X .2017 .1310372$

Germano, G. D., Brito, L. B., \& Capellini, S. A. (2017). The opinion of parents and teachers of students with learning disorders regarding executive function skills. Revista Cefac, 19(5), 674-682. https://doi.org/10.1590/1982-0216201719510817

Gozun, O. \& Yikmis, A. (2004). Öğretmen Adaylarının Kaynaştırma Konusunda Bilgilendirilmelerinin Kaynaştırmaya Yönelik Tutumlarının Değişimindeki Etkililiği [The Effectiveness of Informing Teacher Candidates on Inclusion in Changing their Attitudes towards Inclusion]. Ankara Üniversitesi Eğitim Bilimleri Fakültesi Özel Eğitim Dergisi, 5(02). Retrieved from https://dspace.ankara.edu.tr/xmlui/bitstream/handle/20.500.12575/47232/495.pdf?sequence=1\&isAllowed=y

Gul, S. O., \& Vuran, S. (2015). Normal sınıflara devam eden özel gereksinimli öğrencilerin kaynaştırma uygulamasına ilişkin görüşleri ve karşılaştıkları sorunlar [Opinions of students with special needs who attend regular classes and the problems they encounter]. Eğitim ve Bilim, 40(180). Retrieved from http://213.14.10.181/index.php/EB/article/view/4205

Guleryuz, S. (2009). Kaynaştırma Eğitimine Devam Eden Engelli Öğrencilerin Akranları Ille İlişkilerinde Karsılaştıkları Sorunların Değerlendirilmesi [Evaluation of Problems Encountered by Students with Disabilities in Inclusive Education in their Relationships with their Peers. Unpublished master's thesis]. Yayımlanmamış yüksek lisans tezi, Selçuk Üniversitesi Sosyal Bilimler Enstitüsü, Konya. Retrieved from http://acikerisimarsiv.selcuk.edu.tr:8080/xmlui/ handle/123456789/8957

Guzel, N. (2014). Kaynaştırma öğrencisi olan ilköğretim öğretmenlerinin kaynaştırma eğitimine ilişkin yaşadıkları sorunlar (Beykoz ilçesi örneği) [Problems the classroom teachers who have mainstreamed students in their classes face (Beykoz district example)]. (Yüksek lisans tezi). Yeditepe Üniversitesi, Sosyal Bilimler Enstitüsü. İstanbul. Retrieved from https://tez.yok.gov.tr/UlusalTezMerkezi/tezDetay.jsp?id=diEcq39zNNk_b1yNR7cFMg\&no=yc1xeUwyTZ9Z4xjQV OUFQA

Harvey, M. W., Yssel, N., Bauserman, A. D., \& Merbler, J. B. (2010). Preservice teacher preparation for inclusion: An exploration of higher education teacher-training institutions. Remedial and Special Education, 31(1), 24-33. https://doi. org/10.1177/0741932508324397

Hornby, G. (2015). Inclusive special education: development of a new theory for the education of children with special

www.ijcrsee.com 
educational needs and disabilities. British Journal of Special Education, 42(3), 234-256. https://doi.org/10.1111/14678578.12101

Jacob, U. S., \& Olisaemeka, A. N. (2016). Mainstreaming Education in the 21st Century: Parameters and Opportunities for Learners with Special Needs. European Scientific Journal, ESJ, 12(10). http://dx.doi.org/10.19044/esj.2016. v12n10p188

Krahe, B. \& Altwasser, C. (2006). Changing negative attitudes towards persons with physical disabilities: An experimental intervention. Journal of Community \& Applied Social Psychology, 16, 59-69. https://doi.org/10.1002/casp.849

Olcay-Gul, S. (2014). Farklılaştırılmış öğretim ve uyarlamalar [Differentiated instruction and adaptations]. Ufuk Üniversitesi Sosyal Bilimler Enstitüsü Dergisi, 5, 111-123. Retrieved from https://ufuk.edu.tr/uploads/page/enstituler/sosyal-bilimler/ ensdergi/say-5/serayolcay_gl.pdf

Oncul, N. (2003). Kaynaştırma Uygulaması Yapılan İlköğretim Okuluna Devam Eden Zihin Özürlü Öğrencinin Bulunduğu Sınıfta Normal Çocuk Annelerinin Kaynaştırma Uygulamasına ilişkin Görüşleri [The Opinions of Mothers of Normal Children in the Class of Mentally Handicapped Students Attending Primary School with Inclusion Application]. (Yüksek Lisans Tezi). Anadolu Üniversitesi Sosyal Bilimler Enstitüsü. Eskişehir. Retrieved from https://hdl.handle.net/11421/3824

Orel, A., Zerey, Z. \& Toret, G. (2004). Sınıf öğretmeni adaylarının kaynaştırmaya yönelik tutumlarının incelenmesi [Examination of primary school teacher candidates' attitudes towards inclusion]. Ankara Üniversitesi Eğitim Bilimleri Fakültesi Özel Eğitim Dergisi, 5(1), 23-33. Retrieved from https://dspace.ankara.edu.tr/xmlui/bitstream/handle/20.500.12575/47224/477. pdf? sequence=1\&isAllowed=y

Ozaydin, L. \& Colak, A. (2011). Okul öncesi öğretmenlerinin kaynaştırma eğitimine ve Okul öncesi eğitimde kaynaştırma eğitimi hizmet içi eğitim programına ilişkin görüşleri [Opinions of pre-school teachers on inclusive education and in-service training program in inclusive education in pre-school education]. Kalem Eğitim ve İnsan Bilimleri Dergisi, 1(1), 189-226. Retrieved from http://www.kalemacademy.com/Cms_Data/Sites/KalemAcademy/Files/KalemAcademyRepository/ sayilar/Sayi1_070kulOncesiOgretmenlerininKaynastirmaEgitimi.pdf

Ozgur, I. (2011). IIlköğretimde kaynaştırma [Inclusion in primary education]. Adana: Karahan Yayınları. https://doi. org/10.1177/0888406417692969

Ozkan, T., \& Tokel, A. (2020). An evaluation of school directors' organisational creativity and managerial effectiveness. New Trends and Issues Proceedings on Humanities and Social Sciences, 7(3), 20-26. https://doi.org/10.18844/prosoc. v7i3.5228

Pliner, S. M., \& Johnson, J. R. (2004). Historical, theoretical, and foundational principles of universal instructional design in higher education. Equity \& Excellence in Education, 37, 105-113. https://doi.org/10.1080/10665680490453913

Sabayleh, O. A., \& Alramamneh, A. K. (2020). Obstacles of implementing educational techniques in special education centres from autism teachers' perspective. Cypriot Journal of Educational Sciences, 15(2), 171-183. https://doi.org/10.18844/ cjes.v15i2.4485

Sadioglu, O. (2011). Sınıf öğretmenlerinin kaynaştırmaya ilişkin sorunları, beklentileri ve önerilerine yönelik nitel bir araştırma. [A qualitative research on primary school teachers' problems, expectations and suggestions regarding inclusion.] (Unpublished doctoral dissertation). Uludağ University, Bursa. Retrieved from https://acikerisim.uludag.edu.tr/ handle/11452/2687

Sadioglu, O., Batu, E.S. \& Bilgin, A. (2012). Sınıf öğretmenlerinin özel gereksinimli öğrencilerin kaynaştırılmasına ilişkin görüşleri [Opinions of classroom teachers on the inclusion of students with special needs]. Uludağ Universitesi Eğitim Fakültesi Dergisi, 25(2), 399-432. Retrieved from https://earsiv.anadolu.edu.tr/xmlui/handle/11421/15598

Sagiroglu, N., \& Uzunboylu, H. (2018). Analysis of the published articles related to autism in Turkey: A model proposal for students. [Türkiyede yayınlanan otizimle ilgili makalelerin incelenmesi: öğrencilere yönelik bir model önerisi.] Journal of Education and Special Education Technology, 4(1), 14-23. https://doi.org/10.18844/jeset.v4i1.4105

Sahamkhadam, N. (2020). Effect of In-service Training on Teachers' Attitudes Towards Inclusion: A Systematic Literature Review. Retrieved from https://www.diva-portal.org/smash/record.jsf?pid=diva2\%3A1449551\&dswid=-75

Sahin, A. (2010). Kaynaştırma Yoluyla Eğitim Gören Öğrencilerin Sosyalleşme Sürecinde Karşılaştığı Sorunların Öğretmen Görüşlerine Göre Incelenmesi [An Investigation of the Problems Encountered by Students Educating Through Inclusion in the Process of Socialization According to Teachers' Views]. Yayımlanmamış yüksek lisans tezi, Atatürk Üniversitesi Sosyal Bilimler Enstitüsü, Erzurum. Retrieved from https://www.atauni.edu.tr/yuklemeler/47492dd7202a6f62c76bb6f7 48cd4a5c.pdf

Sarac, T., \& Colak, A. (2012). Opinions and suggestions of primary school teachers about the problems they face in the process of mainstreaming. Retrieved from https://earsiv.anadolu.edu.tr/xmlui/handle/11421/15145

Sardohan Yildirim, A. E., \& Akcamete, G. (2018). Examination of views and suggestions about participation of families of children with special needs in individualised education programme. Cypriot Journal of Educational Sciences, 13(1), 31-40. https://doi.org/10.18844/cjes.v13i1.3367

Sarıcam, H., Deveci, M., \& Ahmetoglu, E. (2020). The Examination of hope, intolerance of uncertainty and resilience levels in parents having disabled children. Global Journal of Psychology Research: New Trends and Issues, 10(1), 118-131. https://doi.org/10.18844/gjpr.v10i1.4398

Saygi, M. (2007). Kuzey Kıbrıs'ta özel eğitim ve kaynaştırma [Special Education and Inclusion in North Cyprus]. Milli Eğitim Dergisi, 1(1), 53-64. Retrieved from http://talimterbiye.mebnet.net/Dergi/3.pdf

Shaw, R. A. (2011). Employing universal design for learning. New Directions for Student Services, 134, 21-33. https://doi. org/10.1002/ss.392

Sucuoglu, B., \& Akalin, S. (2010). An alternative view to mainstreaming classes: Examining instructional characteristics with environmental behavioral assessment. Retrieved from https://dspace.ankara.edu.tr/xmlui/bitstream/ handle/20.500.12575/47287/17295.pdf? sequence=1\&isAllowed=y

Taspinar, F. (2019). The An evaluation of school directors' and teachers' views about supervisors' communication skills. Contemporary Educational Research Journal, 9(2), 21-38. Retrieved from https://doi.org/10.18844/cerj.v9i2.3970

Uzunboylu, H. (2019). Assessment of Student Scores Based on Specific Variables in the Web-Assisted English Grammar Exercises. World Journal on Educational Technology: Current Issues, 11(3), 205-219. https://doi.org/10.18844/wjet. v11i3.4262 
Voltz, D. L., Brazil, N., \& Ford, A. (2008). What matters most in mainstreaming education: A practical guide for moving forward. Intervention in School and Clinic, 37(1), 23-30. https://doi.org/10.1177/105345120103700105

Vural, M., \& Yikmis, A. (2008). Determining the studies of inclusive class teachers on the adaptation of teaching. Abant İzzet Baysal University Faculty of Education Journal. Retrieved from https://dergipark.org.tr/en/pub/aibuefd/issue/1495/18090

Wenglinsky, H. (2000). How teaching matters: Bringing the classroom back into discussions of teacher quality. Princeton, $\mathrm{NJ}$ : Educational Testing Service, PolicyInformation Center. (ERIC Document Reproduction). Retrieved from https://eric. ed.gov/?id=ED447128

Yaman, A. (2017). Determination of classroom teachers' views on the development and implementation of individualized education programs for students educated with the mainstreaming model (Master's thesis, Necmettin Erbakan University Institute of Educational Sciences) Service No. ED447128). Retrieved from https://acikerisim.erbakan.edu.tr/ xmlui/handle/20.500.12452/3284

Zagona, A. L., Kurth, J. A., \& MacFarland, S. Z. (2017). Teachers' views of their preparation for inclusive education and collaboration. Teacher Education and Special Education, 40(3), 163-178

Zeff, R. (2007). Universal design across the curriculum. New Directions for Higher Education, 137, 27-44. Retrieved from https://eric.ed.gov/?id=EJ760534 
Gur, P., \& Yikmis, A. (2021). Determining practices of classroom teachers who have mainstreaming and special needs students in their classes, International Journal of Cognitive Research in Science, Engineering and Education (IJCRSEE), 9(2), 227-239. 